\title{
Impacts of Socio-culture on the Development of Autonomous Learning: A Lens of Vietnamese Context
}

\author{
Cao Thanh Nguyen (Corresponding author) \\ Faculty of Education, La Trobe University \\ Melbourne Victoria 3086, Australia \\ Tel: 03-9479-2737Ｅ-mail: thanhthu7580@yahoo.com
}

Received: August 11, 2011 Accepted: August 16, 2011 Published: December 1, 2011

doi:10.5296/jse.v1i1.866ＵRL: http://dx.doi.org/10.5296/jse.v1i1.866

\begin{abstract}
The paper examines the influences of socio-culture on the development of autonomous learning of Vietnamese students. This study was documented from a number of researchers who have devoted their research on autonomous learning and it's conjunction with native social-cultural influences. The key focus of the paper is to identify how socio-cultural factors impact on student's autonomous learning in Vietnam. The results are important as they provide the researcher a review for a further study.
\end{abstract}

Keywords: Autonomous learning, Social-cultural influence, Vietnamese students 


\section{Macrothink}

\section{Introduction}

Considerable research has indicated that autonomous learning is a part of an ongoing, lifelong process of education that fosters the continuing growth of students' capabilities (Kesten, 1987; Voller, 1997; Champagne et al, 2001; Cotteral, 2003; Teaching Expertise, 2004). The process of forming autonomous learning in education is often complex, in which the influences of socio-cultural factors on education in general and students' learning in particular are considerable. According to Hanrahan (1998); Sinclair (2007) and Lamb (2009), the learning environment including traditional-cultural aspects crucially impacts on students' learning, especially on autonomy in learning. Taking context in Vietnam this paper attempts to depict and examine Vietnamese culture that may constrain or facilitate students to learn autonomously.

\section{A literature of autonomous learning}

The original definition of autonomous learning was first conceived during a series of workshops conducted by the scholar Holec in 1981. In French, his definition is read as:

L'autnomie de I'apprentissage est la capacite' de I'apprenant a`prendre en charge son apprentissage, c’est a`dire la capacite’ a`:

- definir des objectifs

- $\quad$ de’terminer des contenus

- $\quad$ choisir des supports et des techniques

- $\quad$ ge’rer le de’roulement de I’apprentissage

- $\quad$ e'valuer I’apprentissage (contenus et forme) (Workshops 17/96, 3/97, 8/97, 17/97)

(Holec, 1981:3)

The English translation of Holec's 1981 French definition reads that:

"Learner autonomy is the ability to take charge of one’s own learning. In other words: to have, and to hold, the responsibility for all the decisions concerning all aspects of this learning:

- Determining the objectives

- Defining the contents and progressions

- $\quad$ Selecting methods and techniques to be used

- Monitoring the procedure of acquisition

- Evaluating what has been acquired

(Holec, 1981:3)

Holec is one of the first people to develop an understanding of autonomous learning which incorporates the fundamental skills which learners need to attain. The typical aspect raised by Holec is that learner autonomy is the ability to undertake learning tasks independently and 
responsibly.

The Quality Improvement Agency (QIA), (2008) states that “autonomous learning means that learners make decisions about their learning rather than relying on their teachers to do it" (13). Consistent with the QIA, Boud (1988) elaborates on learning autonomy, arguing that it is a process in which the learner works independently from the teacher and actively builds up his or her learning competence. In this case, learners see teachers as resources. Therefore, the autonomous learner is someone who takes increased responsibility for their education, particularly in situations where the skills necessary needed to make decisions and solve problems are highly regarded.

Boud (1988) continues by listing a range of situations where students could take the initiative:

- $\quad$ identifying learning needs,

- $\quad$ setting goals,

- $\quad$ planning learning activities,

- finding resources needed for learning,

- working collaboratively with others,

- $\quad$ selecting learning projects,

- creating 'problems' to tackle,

- choosing where and when they will learn,

- using teachers as guides and counsellors rather than instructors,

- opting to undertake additional non teacher-directed work, such as learning through independent (structured) learning materials,

- determining criteria to apply to their work,

- $\quad$ engaging in self-assessment,

- learning outside the confines of the educational institution, for example in a work setting,

- deciding when learning is complete,

- reflecting on their learning processes,

- making significant decisions about any of these matters, that is, decisions with which they will have to live

(Boud, 1988: 23)

Summarising the main points from the above statements, it seems that, almost all of the factors serve the purpose of the development of autonomy in learning. The noteworthy points include: working independently, collaborative learning, problem solving, using resources, 
decision making, and setting and determining learning goals. They are all relevant to fostering autonomous learning in education in general and in higher education in particular. In one important sense, the issue of whether autonomous learning productively works, it is considerably impacted by the learning environment where shape student's learning styles.

1. The differences between learning styles, and approaches to learning, in Western cultures and Asian cultures

The issue of student's learning style differences between Western and Asian cultures has drawn attention of researchers such as Biggs (2007), Littlewood (1999), Ballard \& Clanchy (1997), Bochner (1986), and Hofstede (1986). This section uses studies from the authors listed above to help illustrate the characteristics of and the differences between education in Western and Asian cultures. Drawing on ideas from the above writers I have created the following table (see table 1) to begin this part of the discussion:

Table 1. Cultural Shift Required in Learning Styles

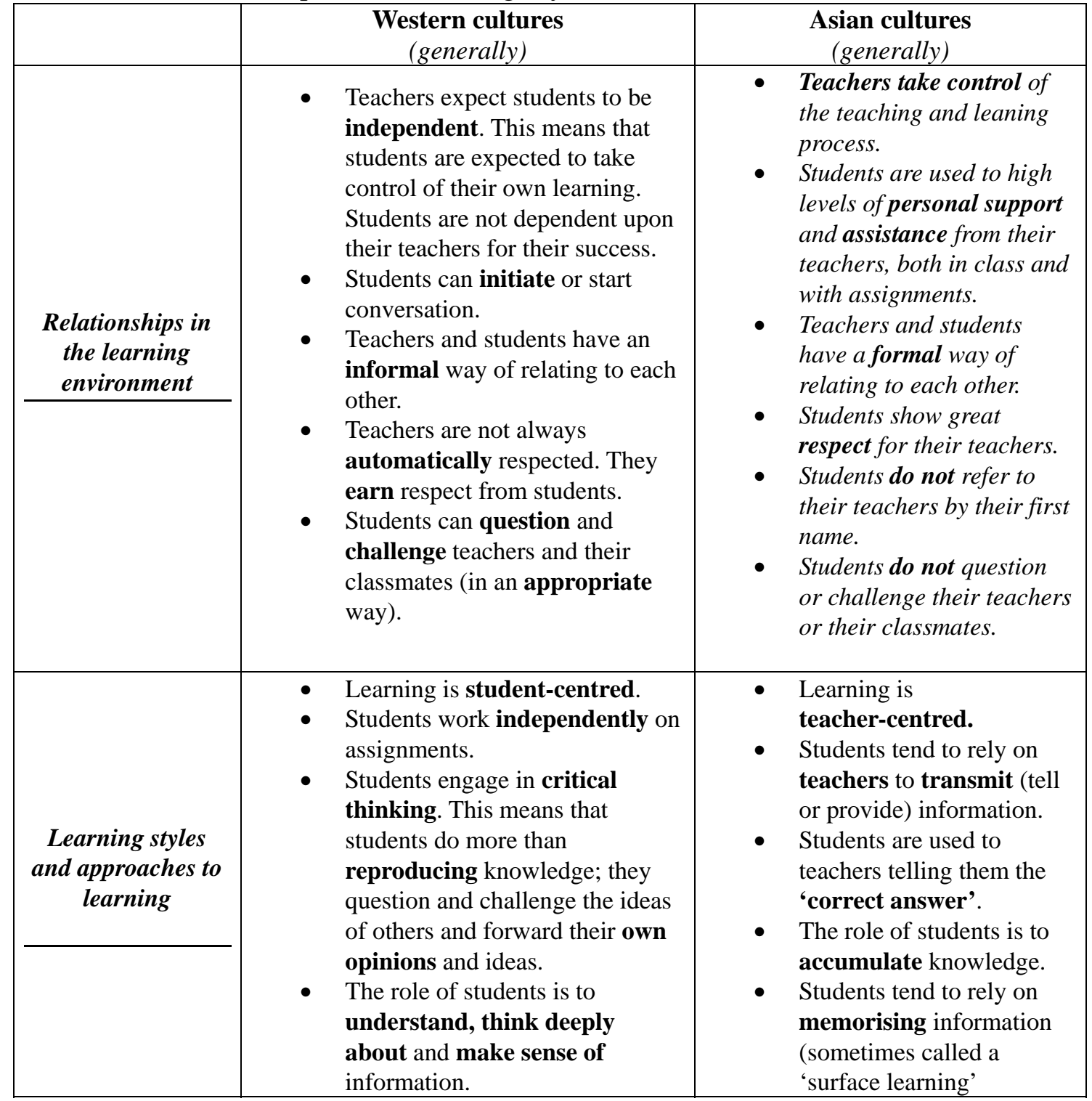




\begin{tabular}{|c|c|c|}
\hline & $\begin{array}{l}\text { - Teachers will not tell students } \\
\text { the 'correct answer'. Many } \\
\text { different 'answers' might be } \\
\text { provided by the teachers and } \\
\text { students are expected to reach } \\
\text { their own conclusions. } \\
\text { - Many different forms of } \\
\text { assessment are used. } \\
\text { Being a successful student } \\
\text { means being able to think } \\
\text { critically about others' ideas and } \\
\text { be creative and original in } \\
\text { constructing new ways of } \\
\text { thinking. } \\
\text { The approach to learning that is } \\
\text { expected by Western students is } \\
\text { often called 'deep learning'. }\end{array}$ & $\begin{array}{l}\text { approach). } \\
\text { - Students tend to } \\
\text { reproduce the information } \\
\text { and knowledge that have } \\
\text { been passed on to them by } \\
\text { their teachers } \\
\text { - } \quad \text { Students work collectively } \\
\text { in study groups. } \\
\text { - Students believe that they } \\
\text { will be successful if they } \\
\text { work hard. } \\
\text { Exams and tests usually } \\
\text { form a major part of the } \\
\text { assessment. } \\
\text { The approach to learning } \\
\text { of students in these } \\
\text { cultures is often called } \\
\text { 'surface learning' }\end{array}$ \\
\hline $\begin{array}{c}\text { Attitudes to } \\
\text { knowledge and } \\
\text { learning }\end{array}$ & $\begin{array}{l}\text { - Ideas can be owned. This is } \\
\text { called intellectual property. } \\
\text { The ideas of others need to be } \\
\text { acknowledged. This means } \\
\text { giving information about who } \\
\text { 'owns' the idea). If the source of } \\
\text { ideas is not acknowledged it is } \\
\text { considered a form of academic } \\
\text { dishonesty. This is called } \\
\text { plagiarism. Plagiarism is } \\
\text { stealing someone else's ideas } \\
\text { and pretending they are your } \\
\text { own. }\end{array}$ & 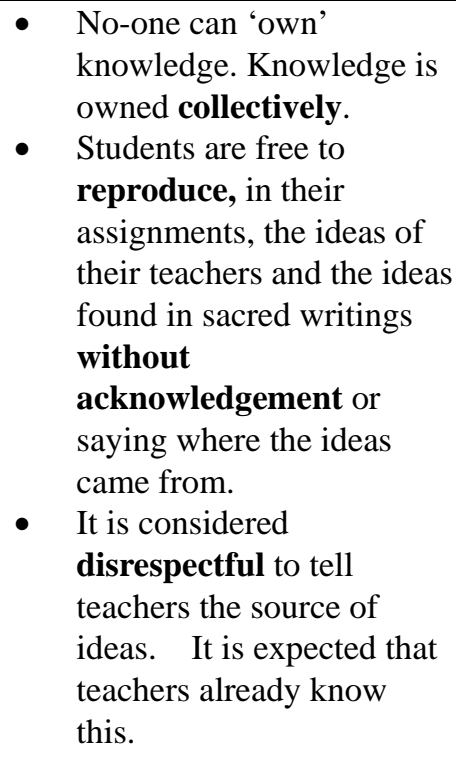 \\
\hline
\end{tabular}

Although these points form the basis for the discussion, it is important to note that all cultures are different and individuals behave differently within each culture. Furthermore, this paper's main aim is not to compare differences between Western and Asian cultures. However, as indicated earlier, the theories of autonomous learning are from Western contexts while the foci of this study is to examine the influences of socio-cultural factors on the development of autonomous learning of students in Vietnam an Asian country. Hence, although the characteristic above do not exactly reflect the current situation, they are empirical and important references to discuss conjunctions between socio-cultural aspects and student' learning in a country like Vietnam.

\section{The socio-cultural influences on student's learning in Vietnam}

As described by a number of scholars, in Vietnam, the social, cultural and educational characteristics have been strongly and deeply influenced by Confucian ideology for centuries (Ellis, 1995; Tong, 2000; Ballard \& Clanchy, 1997; Biggs, 1996; Nguyen, 2005; Pho, 1999). Almost all of these authors agree that the fundamental ideas of Confucius are to build up a society through harmony and hierarchy. In Vietnam, one of the countries that was most influenced by Confucian ideology, there are three relationships which appear to be most important in society: King-subject; Teacher-pupil and Father-child. This was reflected through the Vietnamese traditional poem:

Vua, Thay, Cha, ay ba ngoi

Kinh tho nhu mot, tre oi ghi long.

The King, the teacher, the father occupy three different positions; but children remember that you should venerate them equally as one unified person (Phuoc, 1975 cited in Irwin, 1995) 
In Vietnam, a country with a long standing existence of Confucius, its influences on society in general and on education in particular are unavoidable. According to Confucianism, the relationship between teachers and pupils is also hierarchical. It is likely that the hierarchical relationship also made the traditional Vietnamese teaching-learning style become teacher-centered, with one-way communication. Hofsted (1991) indicated that there were four dimensions of cultural variability. One of them was the large versus small power distance. Vietnam as well as other Asian countries which were influenced by a Confucian tradition was listed in the large power distance culture (Ellis, 1995). In such large power distance societies, the teacher-student relationship is unequal; students are dependent on and should be respectful of their teachers.

Additionally, maintenance of harmony is one of the salient characteristics of Confucian culture. People tend to maintain friendly relations and avoid hurting others' feelings, especially of teachers, parents and elderly people ((Biggs, 1996; Jin \& Contazzi, 1997; Chang \& Chin, 1999). Therefore, maintenance of face, one’s dignity, self-respect and prestige are very important in Vietnamese communities as well as in the classroom. Arguing and discussing with teachers, parents or elder people is often considered as 'rude' and 'disrespectful'. Vietnamese students therefore seem to avoid arguing and debating with others about disagreement of ideas; if they think differently from other people they often do not write or say their own thoughts and they seem to be expected to do what the majority think and value. That is one of the reasons why Western lecturers do not often get feedback from Vietnamese students. Rosenthal, Russell \& Thomson (2006) conclude that different attitudes to the authority of teacher and materials and different modes of teacher-student interaction may also contribute to the difficulties of international students with academic adjustment.

Both inside and outside the classroom Vietnamese teachers are expected to be a "guru" and a reverential superior in terms of his/her "wisdom” (McLaren, 1998: 175; Hofstede, 1986 cited in Ellis, 1995: 14; Pho, 1999: 15).In fact, the teachings of Confucius have been acutely engraved on Vietnamese students' minds and the shifting from one evolution to the other may be time-consuming, thorny and "easier said than done” (Mc Laren, 1998: 174 cited in Vu, 2006:6). For instance:

- “ " Nhat tu vi su, ban tu vi su” (translated into English "You must respect the person who teaches you only a word, even half a word and call him your teacher” Thu, 2005:4)

- “ Khong thay do may lam nen”( translated into English "Without the teacher, you can not do anything” (Vu, 2006: 6)

For this reason, students may appear to stay away from debating bluntly and straightforwardly and may incur the misperceptions of their approach as rudeness, discourteousness, impoliteness or disrespectfulness. This is recognized by Phan (2001: 300).

Furthermore, teachers are considered as the passer of knowledge and students as the receivers of knowledge. Teachers generally control their pupils through both legitimated authority and moral norms. In other words, pupils have to follow their teachers' instructions without criticism. According to McLaren (1998), in the large power societies, "teachers are 
considered wise, authority figures whose word has great weight”. In other words, what teachers say are unquestioned standard norms. Furthermore, the position of teachers in traditional Vietnamese values is likely to be higher than that of parents. This is reflected in the order of three words in the proverb: "Vua-Thay-Cha" (King-Teacher-Father). The teacher was the second only after the King. It is not surprising that Hofsted (1986) states that in the large power distance societies "in teacher/student conflicts, parents are expected to side with the teacher". Therefore, "the educational process is teacher-centered; in the classroom there is supposed to be a strict order with the teacher initiating communication; students in class speak up only when invited to" (Hofsted, 1991).

\section{Discussions}

It is worth noting that almost all of the ideas of Confucian ideology are inclined to the good, and the ideas appear to be meaningful in any society. For instance Confucius calls people to: live together in peace; live in harmony; respect each other; avoid doing things cruelly. However, in the region of education, some ideas of Confucius appear not to be suitable, especially for autonomous learning. In other words, the behaviours and attitudes reflected in Confucian ideology seem to be contrary to the theory of autonomous learning which highly praises independence, responsibility and decision making.

As indicated earlier, to be autonomous in learning, students are required to be creative, responsible and cooperate in their learning, while Vietnamese education culture appears not to support students to do so. In other words, it constrains students to learn independently. As referenced below, according to Confucian ideas, students are taught to be obedient and not to argue with others, especially with teachers. In brief, Confucius prefers students to learn, to think and to behave intrinsically rather than extrinsically and to learn collectivistically rather than individually.

Typically, in Vietnamese classrooms, every single action of students is under strict management of teachers. While, as indicated by scholars, the classroom environment is one of the most crucial factors affecting student' learning achievement, and students are not allowed to criticise teachers even when they do not totally agree with the teachers. Embedded in students' thoughts is the assumed absolute authority of teachers. As defaulted, in classroom, teachers often act as knowledge providers, and students are the receivers. The interactive communication between teachers and students is rare. Therefore, learning in such an environment, students seem to have no opportunity to exhibit their creativeness and independence although they are capable of doing so.

With a positive perspective Vietnamese students are not totally passive and dependent, and can in fact learn productively if they are well facilitated. However, within a bounded educational system such as Vietnam, students are less likely to be given opportunities to exhibit their ability in learning. There is a saying in Vietnamese " $\mathrm{O}$ bau thi tron, o ong thi dai”, and it roughly translates into English: "characteristics of a person are formed by society where she/he lives”. In certain degrees, this saying appears true towards Vietnamese students who are not totally passive and dependent in their learning but are restrained by socio-cultural factors. 
However, in one important sense, it does not mean that the socio-cultural influences will permanently remain on student's learning styles in Vietnam. Significant attempts by Vietnamese government in general and educators in particular are reviewing the educational system.

In the mean time, both teacher and student should try to do something to improve the learning scopes. Teachers should not keep their authority as an absolute power in classroom. Once the gap between teachers and students is reduced, the students' learning would most probably be more productive. Extending from this thought, in an important sense, teachers could act themselves as students, especially in terms of fostering autonomous learning. Why do teachers need to act as learners? Breen (1997: 104) claims that "an essential precondition for the teacher to be able to foster autonomous learning is an explicit awareness of the teacher's own self as a learner”. Clearly, if teachers don't participate in their students' learning, they will find it difficult to understand students' learning characteristics. Moreover, the awareness of teachers as learners also helps teachers to determine when they are able to act autonomously and when they are not able to do so (Breen, 1997:105). Consistent with this, Little (2000: 45) states that "teachers can only develop learner autonomy if they themselves are autonomous... the development of learner autonomy depends on the development of teacher autonomy”. Hence, if teachers are also autonomous, they will understand more about the learner's styles, strengths and weaknesses.

\section{Conclusion}

The paper has brought some discussion of the influences of socio-cultural factors on students' autonomous learning. As reviewed by a number of scholars, autonomous learning is crucial step for students as it will equip them with the essential skills to learn more productively at universities and to work more effectively after university. However, autonomous learning seems to only work well in supported environments where there are less socio-cultural constraints. The facilitation of socio-cultural factors to the development of autonomous learning seems to out of place in Vietnam. In a broader scope of a continued study, this concern is expected to be more adequately examined and addressed.

\section{References}

Biggs, J. (1996). Western misperceptions of the Confucian heritage learning culture. CERC and ACER, Hong Kong: The Central Printing Press.

Biggs, J. B. and Tang, C. (2007). Teaching for quality learning at university. Open University Press/Mc Graw-Hill Education.

Ballard, B., \& Clanchy, J. (1997). Teaching international students: A brief guide for lecturers and supervisors: Deakin ACT, IDP Australia.

Bochner, S. (1986). Culture shock: psychological reactions to unfamiliar environments. London: Methuen.

Boud, D. e. (Ed.). (1988). Developing student autonomy in learning (2nd edition ed.). New York USA: Nichols Publishing Company. 
Chang, V. \& Chin, K, L. (1999). Cultural issues in teaching and learning. Journal of the Australian and New Zealand student services Association

Champagne, M.-F., Clayton, T., Dimmitt, N., Laszewski, M., Savage, W., Shaw, J., et al. (2001). The assessment of learner autonomy and language learning. New Insights, 15, 26-33.

Cotterall, S. (2003). Promoting learning autonomy through an academic writing course. Biennial Tertiary Writing Network Colloquium 5.

Ellis, G. (1995). Teaching and Learning Styles in Vietnam: Lessons for Australian Educators. Journal of Vietnamese Studies, 8, 9-16.

Fosenthal, D. A, Russell, J. V. \& Thomson, G. D. (2006) A growing experience: The health and well-being of international students at the university of Melbourne. The University of Melbourne, Australia.

Hanrahan, M. (1998) The effect of learning environment factors on students' motivation and learning. International Journal of Science Education 20 (6) p 737-753. http://dx.doi.org/10.1080/0950069980200609

Holec, H. (1981). Autonomie et apprentissage des langues e'trange'res: Strasbourg: Council of Europe.

Hofstede, G. (1986). Cultural difrrences in teaching and learning. International Journal of $\begin{array}{lllll}\text { Intercultural } \quad \text { Relations, } & \text { Vol. } & 10, & \text { pp. }\end{array}$ http://dx.doi.org/10.1016/0147-1767(86)90015-5

Hofstede, G. (1991). Cultures and Organizations: Software of the mind. HarperCollinsPublishers. London.

Irwin, H. (1995). Communicating with Asia: Understanding people and customs. New South Wales: Allan \& Unwin Pty Ltd.

Jin, L \& Cortazzi, M (1997) The culture the learner brings: a bridge or a barrier? In Byram M \& Fleming M Language Learning in Intercultural Perspective. Cambridge Language Teaching Library, Cambridge University Press.

Kesten, C. (1987). Independent learning. Saskatchewan Education.

Lamb, T. (2009). Controlling learning: Learners' voices and relationships between motivation and learner autonomy. In S. Toogood, R. Pemberton \& A. Barfield (Eds.), Maintaining control: Autonomy and Language learning (pp.67-86). Hong Kong University Press.

Littlewood, W. (1999). Defining and developing autonomy in East Asian contexts. Applied Linguistics, 71-94. http://dx.doi.org/10.1093/applin/20.1.71

McLaren, M. (1998). Interpreting culture differences. Peter Francis publisher. UK.

Nguyen, V.H (2005). Changes in teaching and learning styles at tertiary level in Vietnam_ Challenges for teachers yet opportunities for students. Unpublished Master of Education Essay, Institute for Education, La Trobe University. 


\section{Macrothink}

Phan, L.H (2001). How do culturally situated notions of "polite” forms influence the way Vietnamese postgraduate students write academic English in Australia? Australian Journal of Education, 45(3), 296-308.

Pho, P, D. (1999). Classroom communication of international Vietnamese students in Australian Universities. M Ed essay, School of Educational Studies, La Trobe University.

Sinclair, B. (2007) The teacher as learner: Developing autonomy in an interactive learning environment. In S. Toogood, R. Pemberton \& A. Barfield (Eds.), Maintaining Control: Autonomy and Language Learning (pp.175-198). Hong Kong University Press.

Teaching Expertise (2004). Developing independent learning skills. Special Needs Information Press.

Thu. (2005). Cultural influences on teaching, learning and communicating style in Vietnamese schools. Unpublished Master of Education Essay, Institution for Education, La Trobe University

The Quality Improvement Agency (QIA), (2008). Independent learning and the expert learner. Teaching and Learning Programe, Retrieved October 2, 2009 from http://teachingandlearning.qia.org.uk/tlp/xcurricula/el/assets/documents/independent_O.pdf.

Tong, C. H. (2000) Confucianism in Chinese Culture. Pelanduk Publication. Selangor, Malyasia.

Vu, T.T. T (2006). How to create new breakthroughs in enhancing the quality training and research of higher education toward 2020? Unpublished Master of Education Essay, Institution for Education, La Trobe University.

Voller, P. (1997). Does the teacher have a role in autonomous learning? London: Longman. 